\title{
Does the use of hedge derivatives improve the credit ratings of Brazilian companies?
}

\author{
Rafael Moreira Antônio ${ }^{1}$ \\ (D) https://orcid.org/0000-0003-1116-808X \\ Email: rafael.antonio@usp.br
}

\author{
Marcelo Augusto Ambrozini ${ }^{1}$ \\ (D) https://orcid.org/0000-0003-0933-6064 \\ Email: marceloambrozini@usp.br \\ Vinícius Medeiros Magnani ${ }^{1}$ \\ (D) https://orcid.org/0000-0002-0069-954X \\ Email: viniciusmagnani@usp.br
}

\author{
Alex A. T. Rathke ${ }^{1}$ \\ (D) https://orcid.org/0000-0003-0397-8904 \\ Email: alex.rathke@usp.br
}

\begin{abstract}
${ }^{1}$ Universidade de São Paulo, Faculdade de Economia, Administração e Contabilidade de Ribeirão Preto, Departamento de Contabilidade, Ribeirão Preto, SP, Brazil
\end{abstract}

Received on 09.09.2018 - Desk acceptance on 10.16.2018 - $3^{\text {rd }}$ version approved on 03.29.2019 - Ahead of print on 06.27.2019

Associate Editor: Eliseu Martins

\begin{abstract}
The purpose of this study is to identify the factors that may explain the attribution of credit ratings to firms, focusing especially on the impact of derivatives. The gap explored by this research lies in the novelty of analyzing how rating agencies perceive the effects caused by information related to derivatives use by Brazilian publicly-traded companies. In addition, this study shifts the previous findings from stock analysts to rating agencies, reinforcing the discussion about the complexity of derivatives in the credit risk assessment process. This research topic is currently of interest due to the adoption of International Financial Reporting Standard (IFRS) 9 (Accounting Pronouncements Committee - CPC - 48), which came into effect in January of 2018. Based on these rules, the main novelty presented in this article was its verification of the effect of the derivatives used by companies in order to hedge their credit ratings, thus helping to fill the empirical gap that exists in the literature from the area. The results found challenge the theory that the use of hedge derivatives is viewed positively by investors. However, although no significant statistical impact was found on the ratings of companies that use derivatives, it was observed that the companies that use derivatives and have the highest notional values were those that received the best ratings from Moody's. With this we broadened the debate about the complexity of the information linked to derivatives use. In the study, 2,090 ratings attributed to non-financial companies with stocks traded on the Brasil, Bolsa, Balcão $[B]^{3}$ exchange were examined between 2010 and 2016 by using panel data analysis, which lends robustness to the analysis and findings. Contrary to the central hypothesis of this research, the results presented here show that, in Brazil, companies that use derivative financial instruments for hedging do not receive the best credit ratings from rating agencies. One of the main contributions of this study is the evidence that Standard \& Poor's and Moody's were unable to consistently incorporate information related to derivatives use, thus broadening the discussion about the complexity of these financial instruments.
\end{abstract}

Keywords: credit ratings, credit rating agencies, credit risk, derivatives, non-financial company.

Correspondence address

Rafael Moreira Antônio

Universidade de São Paulo, Faculdade de Economia, Administração e Contabilidade de Ribeirão Preto, Departamento de Contabilidade Avenida Bandeirantes, 3900 - CEP 14040-900

Monte Alegre - Ribeirão Preto - SP - Brazil 


\section{INTRODUCTION}

The aim of this study is to verify whether companies that use derivative financial instruments, especially those that use them for hedging purposes, have better credit ratings that those that do not use these financial instruments.

According to Hull (2016), a derivative is a financial instrument whose value depends on (or derives from) the values of other underlying variables. These variables are the prices of traded assets. For example, one option involving stocks is a derivative whose value depends on the price of the stock traded. In contrast, credit ratings are issued by credit rating agencies and reflect the ability of the companies assessed to honor their financial commitments. In addition, ratings represent the opinion and judgement of credit analysts and rating agencies, which are responsible for monitoring and issuing the scores of a particular company.

The relationship between derivatives use and ratings warrants attention due to its absence in the Brazilian literature and to the fact that the use of these financial instruments has exhibited important growth in recent years.

Another relevant aspect relates to the complexity of derivatives, as indicated by some of the literature, notably highlighted in the studies by Campbell, Downes, and Schwartz (2015), Chang, Donohoe, and Sougiannis (2016), and Antônio, Lima, and Rathke (2019). The complexity can make it difficult to analyze and interpret the dynamics surrounding the derivatives, transactions, and information generated by the use of these instruments. The difficulty in understanding and interpreting these can lead to a superficial analysis that does not completely (or for the most part) incorporate the relevant aspects related to the risks of using derivatives.

In the Brazilian context, the complexity in the accounting treatment of financial instruments is indicated and highlighted by Gelbcke, Santos, Iudícibus, and Martins (2018). More specifically, Gelbcke et al. (2018) emphasize that keeping an accounting record of financial instruments is not an easy task given that, in order to record these instruments, previous knowledge of capital and credit markets is needed, as well as knowledge of statistical and financial mathematics tools.

In addition to the as yet unexplored relationship between ratings and the use of derivatives (and their complexity), in January of 2018, International Financial Reporting Standard 9 (IFRS, 2018) came into effect in
Brazil via the adoption of Technical Pronouncement $n$. 48 (Accounting Pronouncements Committee - CPC, 2016), called Financial Instruments. This standard substituted the previous regulation, indicated by Gelbcke et al. (2018) as presenting complex rules regarding the accounting treatment of these instruments. Now is therefore an appropriate moment for this study.

Based on all the above, this study is warranted due to the need to understand, comprehensively and in detail, the dynamics involved in the attributions and alterations of ratings and how credit rating agencies incorporate information related to companies' adoption of derivative financial instruments.

The results of this study indicated that the companies that used derivative financial instruments for hedging purposes did not receive the best ratings, isolating the other factors that would affect the credit rating. These results oppose the theory that derivatives use is viewed positively by investors, as indicated by Koonce, Miller, and Winchel (2015), and reinforces the understanding regarding the complexity of derivatives and the difficulty that lies in interpreting the impact of these financial instruments.

Although no statistically significant impact was found on the ratings of companies that used derivatives - the credit rating agencies did not differentiate between derivative users or not - it was observed that, among the companies that used derivatives, those that presented the highest notional values received the best ratings from Moody's, and this group of companies was also not differentiated in any way by Standard \& Poor's (S\&P). This may reveal that it is difficult for the agencies analyzed here to incorporate this financial information. In light of the above, the results of this research suggest that these agencies were unable to consistently incorporate information related to derivatives use. To carry out this study and obtain the results, 2,090 ratings were used and the non-financial companies listed on the Brasil, Bolsa, Balcão [B] $]^{3}$ exchange between 2010 and 2016 were analyzed by means of panel data analysis, thus making the analyses and findings more robust.

This research is organized in five parts, and is composed of this introduction, followed by a review of the relevant studies available in the literature from the area. Subsequently, the methodological aspects are presented, followed by an analysis of the results and the concluding remarks. 


\section{THEORETICAL FRAMEWORK}

Part of the financial risk management carried out by companies is done through the use of derivative financial instruments. With this, companies hope to eliminate or reduce the exposure of their results (revenues, earnings, and cash flow, for example) to unfavorable fluctuations in exchange rates, interest rates, and commodity prices. In this context, Bodie et al. (2014) highlighted that derivatives play an extensive and ever more relevant role in financial markets. In addition, Bodnar and Gebhardt (1999) indicated that there was greater concern about the volatility of exchange rates, interest rates, asset prices on the securities market, and commodity prices than was observed in previous decades.

For Hull, Predescu, and White (2004), derivatives have the potential to enable companies to exchange and manage credit risks, in the same way as market risks. Meanwhile, for Chang et al. (2016), companies routinely endeavor to manage risks, with the aim of separating cash flows and profits from unfavorable changes in interest rates, exchange rates, and commodity prices. Moreover, the use of these financial instruments for hedging purposes was viewed positively by investors, who were more satisfied with the managers of companies that used derivatives, as indicated by Koonce, Lipe, and McAnally $(2008,2015)$. These arguments are fundamental to the hypothesis developed and tested in this study, since companies that use derivatives for hedging purposes are expected to receive the best ratings in comparison with those that do not use this risk management device.

It should be mentioned that the aspects related to the positive perception of hedge derivatives use by investors, as clarified by the studies from Koonce et al. $(2008,2015)$, and the points regarding the complexity of these financial instruments, presented by Kawaller (2004), Campbell (2015), Chang et al. (2016), and Antônio et al. (2019), permeate the elaboration of the research hypothesis. Therefore, the studies presented below in this review are relevant for understanding the formulation of this study.

Although derivatives use has been seen positively by investors in general, the study and the results of Claußen, Löhr, and Rösch (2014) revealed that ratings were insufficient metrics for measuring the risks of structured products, such as the risks inherent to derivatives use, for example. Along these lines, some studies have highlighted the difficulty in understanding the information associated with derivatives use. Standing out among these studies are those of Kawaller (2004), Campbell (2015), Chang et al. (2016), and Antônio et al. (2019).

Campbell (2015) highlighted that the results of his study suggest that the cash flow hedging disclosures linked to Financial Accounting Standards Board rule n. 133 (FASB, 1999) were complex and incomplete; while, along these same lines, Chang et al. (2016) argued that derivatives represent one of the most complex types of financial contracts, thus creating a significant challenge for companies that use these instruments to report them.

Based on the degree of complexity of certain information, Plumlee (2003) investigated the relationship between complex information and the use of this information by analysts and highlighted that: either analysts' abilities to incorporate specific information, reflected in their predictions, are a decreasing function of the complexity of these instruments, or analysts choose not to assimilate complex information, since the costs of such assimilation would exceed its benefits. It is important to highlight that the research developed by Plumlee (2003) used the complexity of information on tax and stock analysts. It is therefore possible to transfer the results found by Plumlee (2003) to the reality of disclosing derivative financial instruments and their assimilation by credit rating agencies and their analysts.

It is important to note that even derivatives users have highlighted that they should be used cautiously, especially depending on the incentives for their inadequate use. Based on answers obtained from applying 420 questionnaires to derivatives users and controllers, Bezzina and Grima (2012) reported that some aspects such as greed, political interference, standards, and inadequate controls encouraged misuse and impeded the appropriate use of derivatives. What draws attention in the results reported in the study developed by Bezzina and Grima (2012) is the fact that the interviewees agreed with the fact that they are able to deal with derivatives, even in complex situations, and, despite this, they answered that they do not have specialist knowledge to deal with derivatives in complex positions. Such duality and conflict between the derivatives users that took part in this research reveals, even for users of these instruments, the degree of complexity of these financial contracts and their dynamics.

Another aspect related to the use of derivative instruments is that, in some cases, part of the information on this use is disclosed in footnotes and not in financial statements, such as in the balance sheet, for example. 
Based on this aspect, Kawaller (2004) highlighted that most derivative contracts are disclosed in off balance sheet items, leading to a lack of transparency. More than this, derivative financial instruments were applied inconsistently from company to company, which led to the FASB embarking on an ambitious project aimed at clarifying and improving the disclosure of these instruments. In the words of Kawaller (2004, p. 1), "taming the derivatives beast".

In addition, it is important to observe that Chang et al. (2016) found evidence that indicated that the various accounting rules implemented with regard to derivatives helped analysts improve their long term forecasts, which suggests that the regulator's effort to improve the rules may have improved the quality of the information disclosed concerning derivatives.

Given that investors view the use of hedge derivatives in a positive light and the complexity of these instruments, the analyses developed in this study have been expanded from analysts (objects of the preliminary studies) to credit rating companies, which may not incorporate - in their entirety - the derivative financial instruments reported in companies' financial statements.

Returning to the aspects related to the complexity of the information contained in hedge instruments, Campbell et al. (2015) highlighted that an unrealized gain based on a cash flow hedge implies that the underlying price of the hedged item (that is, the commodity price, exchange rate, or interest rate) has moved in a direction that will negatively affect company profits after the hedge matures. In addition, the authors listed that unrealized gains/losses in cash flow hedges are negatively associated with future gains and that investor expectations, reflected in stock price volatility, appeared not to anticipate this relationship, indicating that information regarding hedges, based on derivatives use, was not adequately used by information users in their corporate evaluations.

In contrast to what was found by Campbell et al. (2015), the study developed by Dadalt, Gay, and Nam (2002) discovered a relationship between derivatives use and information asymmetry, and analyst forecasts were adopted as an alternative proxy for informational asymmetry. The results presented by Dadalt et al. (2002) indicated that, for companies that used derivatives (especially foreign currency ones), the analysts' profit forecasts were more precise and less dispersed. This reveals that the hedging carried out based on derivatives use was able to protect companies from fluctuations in the underlying assets. Thus, the use of derivative financial instruments may provide greater stability to profits and, consequently, protect companies from interest rate, exchange rate, and commodity price fluctuations.

More recently, Chang et al. (2016) investigated whether the complexity of derivatives is reflected in the properties of market analysts' predictions. It was observed that analysts' profit forecasts, for companies that began to use derivatives (new users), were less accurate and presented greater dispersion in contrast to what was recorded, years before, by Dadalt et al. (2002). It is helpful to consider that analysts and investors can better process the information contained in derivative financial instruments and their hedges. This is intimately related to the quality of the disclosure of this information to financial report users.

In Brazil, Antônio et al. (2019) analyzed the bias of the forecasts of analysts in companies that used derivatives in comparison with those that did not. The research was carried out between 2006 and 2014 and the sample was composed of non-financial companies of the $[\mathrm{B}]^{3}$. The researchers analyzed the bias in the forecasts of revenues, earnings before interest, taxes, depreciation, and amortization (EBITDA), and earnings per share (EPS), and concluded that there was no bias in the revenues forecasts and that this was lower in the EPS forecasts. With relation to the EBITDA forecasts, the bias in the predictions was greater; although Antônio et al. (2019) highlight that analysts may include information on derivatives in their estimates, the finding that there was greater bias in the EBITDA forecasts might indicate the complexity of derivatives, especially those classified and measured by fair value and recognized in company results.

This item listed fundamental aspects related to the development of the research hypotheses tested in this study. Although derivatives use has been viewed positively by investors, some of the literature highlights the complexity of the information linked to them. With this, there are indications that, given the complexity of structured financial products (such as derivatives), ratings have proven to be insufficient metrics for measuring the risks linked to these financial instruments. 


\section{INVESTIGATION STRATEGY}

\subsection{Methodological Aspects}

The focus of this study lies in analyzing the ability of rating agencies to incorporate items that go beyond financial indicators, as indicated by Ederington (1985), who highlighted that agencies include more variables in their analyses than a statistical model can incorporate.
With the aim of analyzing the subjective factors behind the issuing of ratings, Table 1 reveals two subjective factors that compose the ratings evaluations of companies that make up the global steel industry and form part of Moody's analysis methodology and are used in a similar way by other agencies. These factors are: business profile with a weight in the overall evaluation of $20 \%$ and financial policies with a weight of $10 \%$.

Table 1

Rating factors and subfactors and their weights used by Moody's

\begin{tabular}{|c|c|c|c|}
\hline Broad rating factors & Weight of factor $(\%)$ & Rating subfactor & Weight of subfactor $(\%)$ \\
\hline Business profile & 20.0 & Business profile & 20.0 \\
\hline Size & 20.0 & Revenues (USD billions) & 20.0 \\
\hline \multirow{3}{*}{ Profitability } & \multirow{3}{*}{22.5} & Average EBIT margin & 10.0 \\
\hline & & Return on assets (EBIT/average tangible assets) & 5.0 \\
\hline & & EBIT/interest & 7.5 \\
\hline Financial policies & 10.0 & Financial policies & 10.0 \\
\hline \multirow{3}{*}{ Cash flow leverage and cover } & \multirow{3}{*}{27.5} & Debt/EBTIDA & 15.0 \\
\hline & & Debt/capital & 5.0 \\
\hline & & (OCF - dividends)/debt & 7.5 \\
\hline Total & 100.0 & & 100.0 \\
\hline
\end{tabular}

$E B I T=$ earnings before interest and taxes; EBITDA = earnings before interest, taxes, depreciation, and amortization; OCF = operating cash flow.

Source: Elaborated by the authors.

This study analyzed non-financial companies listed on the $[\mathrm{B}]^{3}$, for which ratings were attributed between January of 2010 and December of 2016, and the choice of the S\&P's, Fitch, and Moody's ratings agencies is based on what was highlighted by Fischer (2015); that is, that the market is dominated by these three agencies. The analysis proposed here therefore covers a cross section from between 2010 and 2016, with the aim of discovering the impact that derivatives use has on ratings, but also identifying the possible financial indicators that can determine ratings and alterations in them. Cross sections have been previously adopted and follow the studies by Hsueh and Liu (1992), Kisgen (2006), Freitas and Minardi (2013), Tonin and Colauto (2015), and Lobo, Paugam Stolowy, and Astolfi (2017).

With relation to the explanatory variables, some have already been previously adopted by Hentschel and Kothari (2001), Damasceno, Artes, and Minardi (2008), Batta, Qiu, and $\mathrm{Yu}$ (2016), and Dehaan (2017). It is worth mentioning that the information needed to calculate the explanatory variables were extracted from the Economatica ${ }^{\circledR}$ and Thomson Reuters Eikon ${ }^{\circledR}$ databases (financial, market, and company risk characteristics, collected quarterly) and Thomson Reuters Eikon ${ }^{\circledR}$ database (credit ratings issued by the agencies). The long-term issuer credit rating was chosen for use, this being the same variable used in the studies developed by Li, Shin, and Moore (2006), Cheng and Subramanyam (2008), Lee (2008), and Batta et al. (2016).

In addition, the database related to the aspects and to the information on the use or not of derivative financial instruments was extracted manually based on the collection and analysis of financial statements, especially in the footnotes of the companies analyzed here. This information was extracted from the Brazilian Securities and Exchange Commission (Comissão de Valores Mobiliários - CVM) website. Table 2 indicates the independent variables, in detail, the importance for the model, the mathematical formulations, as well as the studies that have already previously adopted them. 
Table 2

Characteristics considered independent variables

\begin{tabular}{|c|c|c|}
\hline \multicolumn{2}{|r|}{ Variables } & Reason \\
\hline \multirow{2}{*}{$\begin{array}{l}\text { Liquidity and ability } \\
\text { to pay }\end{array}$} & $\begin{array}{c}\text { General liquidity } \\
(\mathrm{CA}+\mathrm{NCA}) /(\mathrm{CL}+\mathrm{NCL})\end{array}$ & $\begin{array}{l}\text { Similarly to what has been indicated previously, this variable } \\
\text { presents an overview of the company's general ability to pay. }\end{array}$ \\
\hline & EBIT/financial expense & Represents the commitment of EBIT to financial expenses. \\
\hline \multirow{2}{*}{$\begin{array}{l}\text { Indebtedness and } \\
\text { capital structure }\end{array}$} & $\begin{array}{l}\text { Third-party capital/total liabilities } \\
\qquad(\mathrm{CL}+\mathrm{NCL}) / \text { total liabilities }\end{array}$ & $\begin{array}{l}\text { As indicated by Kisgen (2006), credit notes would influence } \\
\text { alterations in capital structure. }\end{array}$ \\
\hline & $\begin{array}{l}\text { Third-party capital/own capital } \\
\text { Total liabilities/NE }\end{array}$ & $\begin{array}{l}\text { Similarly to what was previously indicated by Kisgen (2006), credit } \\
\text { notes would influence alterations in capital structure. }\end{array}$ \\
\hline Profitability indicators & $\begin{array}{c}\text { ROI } \\
\text { (EBIT/average capital invested) } \times(1-\mathrm{IT} / \mathrm{SCNP})\end{array}$ & $\begin{array}{l}\text { Return on investment generated by the company. Indicator frequently } \\
\text { used in evaluating investments. }\end{array}$ \\
\hline \multirow{3}{*}{ Risk indicators } & $\begin{array}{c}D F L \\
{\left[R O A+\left(R O A-K_{i}\right) \times L / N E\right] / R O A}\end{array}$ & $\begin{array}{l}\text { Represents the company's degree of financial leverage and is } \\
\text { a fundamental aspect in evaluating the ability to pay. Used by } \\
\text { Hentschel and Kothari (2001) and by Dehaan (2017). In addition, } \\
\text { Murcia, Dal-Ri Murcia, Rover, and Borba (2014) indicated leverage } \\
\text { as a determinant factor of ratings in Brazilian companies. }\end{array}$ \\
\hline & $\begin{array}{c}\text { Share volatilities } \\
\text { NL (Share pricet/share pricet-1) }\end{array}$ & $\begin{array}{l}\text { Indicated by Hentschel and Kothari (2001) that risk management that } \\
\text { seeks to reduce the volatility of share returns is known as hedging. } \\
\text { This variable was also used by Batta et al. (2016). }\end{array}$ \\
\hline & $\begin{array}{l}\text { Company betas } \\
\text { Covariance (assets, } \\
\text { lbovespa)/variance } \\
\text { Ibovespa) }\end{array}$ & $\begin{array}{l}\text { It is the CAPM } \beta \text { estimated based on the daily shares returns. Variable } \\
\text { previously used by Hentschel and Kothari (2001) and Cheng and } \\
\text { Subramanyam (2008). }\end{array}$ \\
\hline \multirow[t]{2}{*}{ Derivatives use } & Use of derivative financial instruments (User) & $\begin{array}{l}\text { Dummy variable that represents the use of one of the derivative } \\
\text { types (term, future, swap, and options), it was previously used by } \\
\text { Hentschel and Kothari (2001) and, similarly, by Batta et al. (2016). In } \\
\text { addition, the studies from Guay (1999), Donohoe (2015), and Chang } \\
\text { et al. (2016) also made similar categorizations. A value of } 1 \text { was } \\
\text { attributed to companies that made use of the financial instruments in } \\
\text { a particular quarter and } 0 \text { to those that did not use them. }\end{array}$ \\
\hline & Notional value of the derivatives/total assets & $\begin{array}{l}\text { Used by Hentschel and Kothari (2001), it aims to identify the amount } \\
\text { of value of a derivative contract in the perception of credit rating } \\
\text { agencies. The notional value is represented by the contractual value } \\
\text { established at the start of the contract converted into domestic } \\
\text { currency (BRL). }\end{array}$ \\
\hline
\end{tabular}

$C A=$ current assets; CAPM = Capital Asset Pricing Model; SCNP = Social Contribution on Net Profits; DFL = degree of financial leverage; Ibovespa = Bovespa index; $I T=$ Income Tax; $N L=$ natural logarithm; $L=$ total liabilities; $C L=C u r r e n t ~ l i a b i l i t i e s ; ~ N E=n e t$ equity; $N C L=$ non-current liabilities; $N C A=$ non-current assets; $R O A=$ return on assets; $R O I=$ return on investment.

Source: Elaborated by the authors.

The panel data approach is used to test the hypotheses of the study. Thus, to support the choice of this methodology and estimate the model, Wooldridge (2010) and Gujarati and Porter (2011) were used as references. The initial model, expressed in equation 1 , with the rating adopted as a dependent variable, was previously used by Bonsall, Koharki, and Neamtiu (2015) and Damasceno et al. (2008) and will serve as the basis for the development of the other models.

$$
\begin{gathered}
\text { Rating }_{i, t}=\alpha+\delta_{1} \text { User }_{i, t}+\beta_{1} \text { Liquidity }_{i, t}+\beta_{2} \text { Structure }_{i, t} \\
\beta_{3} \text { Profitability }_{i, t}+\beta_{4} \text { Ris }_{i, t}+\beta_{5} \text { Size }_{i, t}+\varepsilon_{i, t}
\end{gathered}
$$

In equation 1, Rating is the credit rating attributed to company $i$ at time $t$; the regression term Liquidity is composed of the variables that establish the liquidity of company $i$ at time $t$, Structure is the term that considers the aspects linked to the indebtedness and to the capital structure of company $i$ at time $t$, Profitability represents the aspects related to the profitability of company $i$ at time $t$, Risk establishes the aspects for capturing the risk of company $i$ at time $t$, and the Size term establishes the aspects for capturing the size of company $i$ at time $t$.
With relation to the User variable, in this initial regression, it is represented by a dummy variable that aims to capture the influence on the ratings of company $i$, which has (1) or does not have (0) any type of derivative financial instrument at time $t$. This classification between users or not of derivatives is aligned with the studies developed by Guay (1999), Donohoe (2015), and Chang et al. (2016). Then, in the second regression model developed, we tried to capture whether the value of the company's derivative financial instrument (relationship between notional value 
and total assets) is reflected in the ratings. This is presented in equation 2.

$$
\text { Rating }_{i, t}=\alpha+\beta_{1} \text { Notional value }_{i, t}+\beta_{2} C_{i, t}+\varepsilon_{i, t}
$$

In equation 2 , the Notional value item is characterized by the ratio between the notional value of the derivatives and the total assets of company $i$ at time $t$. It is important to highlight that this variable is similar to the one used by Hentschel and Kothari (2001). The main difference is that Hentschel and Kothari (2001) used the ratio between the notional value of all the derivatives contracts reported (deflated by the sum of the book value of liabilities) and the market value of net equity, both measured at the start of the year for which the information derived is collected [derivatives/market value (MV) of assets].

In turn, the measure expressed by the variables Notional value/Total assets seeks to capture whether the size of the hedge adopted by the company has any influence on the evaluations and ratings given; that is, we aim to capture the hedge perceived by the agencies based on the positions assumed by the companies. Above all, it is important to highlight that a positive relationship is expected between the hedged value and the rating attributed to the companies, given that the sample of companies analyzed here states that it uses derivatives for hedging purposes.

\section{RESULTS}

\subsection{Preliminary Data Analysis}

As previously highlighted, the aim of this study was to investigate whether companies that use hedge derivatives received better credit ratings than those that did not use these financial instruments. The elaboration of this hypothesis is based on the indication made by Ederington (1985), that rating agencies consider more variables than a statistical model can incorporate and also on the fact that derivatives use has been viewed positively by investors, as pointed out by Koonce et al. (2015). Thus, in this study, it was verified whether derivatives use was considered to be relevant and positive information by the agencies.

In order to provide the results with more robustness, the tests were carried out based on three ratings categorizations. These categorizations are the most recurrent ones in the literature on the topic and seek to capture ratings alterations in different ways. The categorizations are presented in Table 3.

Table 3

Categorization of the dependent variables (ratings)

\begin{tabular}{|c|c|c|c|c|}
\hline \multicolumn{5}{|c|}{ Part A - Studies on which the categorization of the dependent variables was based on } \\
\hline \multicolumn{3}{|c|}{ Studies } & Categorization & Numeric scale \\
\hline \multicolumn{3}{|c|}{ Damasceno et al. (2008) } & A & $0-6$ \\
\hline \multicolumn{3}{|c|}{ Johnston, Markov, and Ramnath (2009), and Lobo et al. (2017) } & B & $1-8$ \\
\hline \multicolumn{3}{|c|}{ Cheng and Subramanyam (2008), Bonsall et al. (2015), and Batta et al. (2016) } & C & $1-22$ \\
\hline \multicolumn{5}{|c|}{ Part B - Detail of the categorizations used according with each study } \\
\hline Categorized variable (A) & Damasceno et al. (2008) & $\begin{array}{l}\text { Categorized variable } \\
\text { (B) }\end{array}$ & Lobo et al. (2017) & Johnston et al. (2009) \\
\hline 0 & AAA & 1 & AAA & AAA \\
\hline 1 & AA & 2 & $\mathrm{AA}$ & AA \\
\hline 2 & $\mathrm{~A}$ & 3 & $\mathrm{~A}$ & $\mathrm{~A}$ \\
\hline 3 & BBB & 4 & BBB & BBB \\
\hline 4 & $\mathrm{BB}$ and $\mathrm{B}$ & 5 & $\mathrm{BB}$ & BB \\
\hline 5 & CCC & 6 & $\mathrm{~B}$ & $\mathrm{~B}$ \\
\hline 6 & CC, C, and D & 7 & $\mathrm{CCC}$ & $\mathrm{CCC}$ \\
\hline- & - & 8 & $\mathrm{CC}$ & Others \\
\hline \multirow{2}{*}{$\begin{array}{l}\text { Categorized variable } \\
\text { (C) }\end{array}$} & \multicolumn{4}{|c|}{ Cheng and Subramanyam (2008), Bonsall et al. (2015), and Batta et al. (2016) } \\
\hline & Moody's & Fit & & Standard \& Poor's \\
\hline 1 & Aaa & & & AAA \\
\hline 2 & Aa1 & & & $\mathrm{AA}+$ \\
\hline 3 & Aa2 & & & AA \\
\hline 4 & Aa3 & & & AA- \\
\hline 5 & A1 & & & A+ \\
\hline 6 & $\mathrm{~A} 2$ & & & A \\
\hline
\end{tabular}


Table 3

Cont.

\begin{tabular}{cccc}
\hline & \multicolumn{3}{c}{ Part B - Detail of the categorizations used according with each study } \\
\hline \multirow{2}{*}{$\begin{array}{c}\text { Categorized variable } \\
(\mathbf{C})\end{array}$} & \multicolumn{2}{c}{ Cheng and Subramanyam (2008), Bonsall et al. (2015), and Batta et al. (2016) } \\
\cline { 2 - 4 } & Moody's & Fitch ratings & Standard \& Poor's \\
\hline 7 & A3 & A- & A- \\
\hline 8 & Baa1 & BBB+ & BBB+ \\
\hline 9 & Baa2 & BBB & BBB \\
\hline 10 & Baa3 & BBB- & BBB- \\
\hline 11 & Ba1 & BB+ & BB \\
\hline 12 & Ba2 & BB & BB- \\
\hline 13 & Ba3 & BB- & B+ \\
\hline 14 & B1 & B+ & B \\
\hline 15 & B2 & B & B- \\
\hline 16 & B3 & B- & CCC+ \\
\hline 17 & Caa1 & CCC & CCC \\
\hline 18 & Caa2 & CCC & CCC- \\
\hline 19 & Caa3 & CCC & CC \\
\hline 20 & Ca & CCC & C \\
\hline 21 & Ca & CCC & D \\
\hline 22 & C & DDD & \\
\hline
\end{tabular}

Source: Elaborated by the authors.

Table 3 presents the three categorizations used in the organization of the dependent variable that composed the tests developed in this research. The use of these categorizations seeks to present the results adherent to the main studies on the topic, since these categorizations are used recurrently in the literature and aim to capture ratings alterations in three different ways.

In this stage, the data used in the study are presented. Table 4 shows the descriptive statistics of the variables used in the proposed models.

Table 4

Types of instruments used by the companies between 2010 and 2016

\begin{tabular}{|c|c|c|c|c|c|}
\hline Variables & Observations & Average & Standard deviation & Minimum & Maximum \\
\hline \multicolumn{6}{|c|}{ Dependent } \\
\hline S\&P'S (A) & $1,569.00$ & 3.68 & 0.61 & 2.00 & 6.00 \\
\hline S\&P'S (B) & $1,569.00$ & 4.81 & 0.81 & 3.00 & 8.00 \\
\hline S\&P'S (C) & $1,569.00$ & 11.61 & 2.27 & 7.00 & 22.00 \\
\hline Moody's (A) & 521.00 & 3.32 & 0.75 & 2.00 & 6.00 \\
\hline Moody's (B) & 521.00 & 4.41 & 0.93 & 3.00 & 8.00 \\
\hline Moody's (C) & 521.00 & 10.46 & 2.51 & 6.00 & 20.00 \\
\hline \multicolumn{6}{|c|}{ Interest } \\
\hline User & $17,752.00$ & 0.21 & 0.41 & 0.00 & 1.00 \\
\hline Notional value & $3,467.00$ & 0.09 & 0.18 & 0.00 & 4.48 \\
\hline \multicolumn{6}{|c|}{ Control } \\
\hline General liquidity & $10,868.00$ & 31.97 & $1,205.98$ & 0.00 & $105,862.70$ \\
\hline Liabilities/(L+NE) & $10,947.00$ & 1.93 & 45.03 & 0.00 & $4,352.44$ \\
\hline EBIT/expenses & $9,986.00$ & 3.52 & 663.91 & $-7,104.00$ & $64,239.70$ \\
\hline ROI & $9,439.00$ & -217.42 & $16,385.97-1$ & $585,881.00$ & $5,999.00$ \\
\hline NL (assets) & $10,948.00$ & 13.83 & 3.07 & 0.00 & 21.18 \\
\hline Leverage & $10,182.00$ & 7.71 & $665.8267-1$ & 11.40 & $64,915.20$ \\
\hline Volatility & $6,506.00$ & 5.56 & 29.84 & 0.00 & 802.10 \\
\hline Beta & $6,783.00$ & 0.73 & 2.08 & -32.17 & 18.56 \\
\hline
\end{tabular}

Note: The results were not presented for Fitch, since the size ( $n$ ) of the regression was inferior to the number of explanatory variables, meaning it was necessary to exclude it. Thus, the analyses were carried out based on the ratings issued by Standard \& Poor's (S\&P) and Moody's.

$E B I T=$ earnings before interest and taxes; $N L=$ natural logarithm; $L=$ total liabilities; $N E=$ net equity; $R O I=$ return on investment.

Source: Elaborated by the authors. 
Table 5 presents the correlation matrix between the variables analyzed in this study. Based on the results reported, it is verified that the credit ratings issued by the agencies are convergent (see positive correlations greater than 0.60 ). In addition, it warrants noting that the variables inserted into the proposed models are not correlated.

Table 5

Correlation matrix between the variables studied

\begin{tabular}{|c|c|c|c|c|c|c|c|c|}
\hline Variables & $\begin{array}{l}\text { S\&P's } \\
\text { (A) }\end{array}$ & Moody's (A) & $\begin{array}{c}\text { S\&P's } \\
\text { (B) }\end{array}$ & Moody's (A) & $\begin{array}{l}\text { S\&P's } \\
\text { (C) }\end{array}$ & $\begin{array}{l}\text { Moody's } \\
\text { (A) }\end{array}$ & Notional & $\begin{array}{l}\text { General } \\
\text { liquidity }\end{array}$ \\
\hline S\&P'S (A) & 1.0000 & & & & & & & \\
\hline Moody's (A) & 0.6903 & 1.0000 & & & & & & \\
\hline S\&P'S (B) & 0.9825 & 0.6975 & 1.0000 & & & & & \\
\hline Moody's (B) & 0.6933 & 0.9745 & 0.7319 & 1.0000 & & & & \\
\hline S\&P'S (C) & 0.9170 & 0.6683 & 0.9351 & 0.7094 & 1.0000 & & & \\
\hline Moody's (C) & 0.6567 & 0.8833 & 0.7021 & 0.9217 & 0.7236 & 1.0000 & & \\
\hline Notional & -0.1902 & -0.0492 & -0.2033 & -0.0846 & -0.2122 & 0.0808 & 1.0000 & \\
\hline General liquidity & 0.1590 & 0.1351 & 0.1207 & 0.0839 & 0.1526 & 0.2175 & 0.4068 & 1.0000 \\
\hline Liabilities/(L+NE) & 0.4814 & 0.4350 & 0.4902 & 0.4426 & 0.5651 & 0.5480 & -0.1665 & 0.2177 \\
\hline EBIT/expenses & -0.0169 & -0.0351 & -0.0152 & -0.0310 & 0.0303 & -0.0329 & -0.0506 & -0.0392 \\
\hline ROI & 0.1964 & 0.2341 & 0.1583 & 0.1821 & 0.0666 & 0.1122 & 0.1520 & 0.0809 \\
\hline NL (assets) & -0.4641 & -0.5223 & -0.4556 & -0.4975 & -0.4821 & -0.6524 & -0.4769 & -0.6845 \\
\hline Leverage & 0.2993 & 0.2864 & 0.4067 & 0.3837 & 0.4080 & 0.4302 & -0.0811 & -0.0364 \\
\hline Volatility & -0.1751 & -0.1533 & -0.1794 & -0.1626 & -0.0929 & -0.1211 & -0.0964 & 0.0137 \\
\hline Beta & 0.0495 & 0.0295 & 0.1004 & 0.0973 & 0.1807 & 0.0548 & -0.3612 & -0.3438 \\
\hline Variables & \multicolumn{2}{|c|}{ Liabilities/(L+NE) } & $\begin{array}{c}\text { EBIT/ } \\
\text { expenses }\end{array}$ & ROI & NL (assets) & Leverage & Volatility & Beta \\
\hline \multicolumn{9}{|l|}{$\mathrm{S} \& \mathrm{P}^{\prime} \mathrm{s}(\mathrm{A})$} \\
\hline \multicolumn{9}{|l|}{ Moody's (A) } \\
\hline \multicolumn{9}{|l|}{ S\&P's (B) } \\
\hline \multicolumn{9}{|l|}{ Moody's (B) } \\
\hline \multicolumn{9}{|l|}{$S \& P^{\prime} S(C)$} \\
\hline \multicolumn{9}{|l|}{ Moody's (C) } \\
\hline \multicolumn{9}{|l|}{ Notional } \\
\hline \multicolumn{9}{|l|}{ General liquidity } \\
\hline Liabilities/(L+NE) & \multicolumn{2}{|c|}{1.0000} & & & & & & \\
\hline EBIT/expenses & \multicolumn{2}{|c|}{-0.0613} & 1.0000 & & & & & \\
\hline ROI & \multicolumn{2}{|c|}{-0.0192} & 0.0364 & 1.0000 & & & & \\
\hline NL (assets) & \multicolumn{2}{|c|}{-0.5240} & -0.0089 & -0.3033 & 1.0000 & & & \\
\hline Leverage & \multicolumn{2}{|c|}{0.2838} & -0.0033 & -0.1483 & -0.2025 & 1.0000 & & \\
\hline Volatility & \multicolumn{2}{|c|}{0.2627} & -0.0357 & -0.0589 & 0.0327 & -0.0902 & 1.0000 & \\
\hline Beta & \multicolumn{2}{|c|}{0.0307} & 0.0923 & -0.1711 & 0.2671 & 0.2568 & 0.1970 & 1.0000 \\
\hline
\end{tabular}

$E B I T=$ earnings before interest and taxes; $N L=$ natural logarithm; $L=$ total liabilities; $N E=$ net equity; $R O I=$ return on investment.

Source: Elaborated by the authors.

\subsection{Incorporation of the Information Related to Derivatives}

Before presenting the results of the proposed models, adherence tests were carried out on the panel data regression models. According to Wooldridge (2006), the estimation methods based on panel data correspond to three estimation types: pooled, fixed effects (FE), and random effects (RE). In order to decide which estimation to choose, three tests were carried out: Chow, Breusch-Pagan, and Hausman (in that order). Table 6 presents the Chow, Breusch-Pagan, and Hausman (robust and non-robust) tests for choosing the most adherent model among those that consider ordinary least squares (OLS), FE, and RE. 
Table 6

Tests for choosing the regression model - Standard \& Poor's (S\&P's) and Moody's Ratings

\begin{tabular}{|c|c|c|c|}
\hline Part A & & S\&P's & \\
\hline Dependent variable & S\&P'S (A) & S\&P'S (B) & S\&P's (C) \\
\hline Variable of interest & User & User & User \\
\hline Chow test & 24.09 & 26.31 & 33.87 \\
\hline $\mathrm{p}$-value & 0.000 & 0.000 & 0.000 \\
\hline Breusch-Pagan test & $2,259.95$ & $1,871.91$ & $2,014.86$ \\
\hline $\mathrm{p}$-value & 0.000 & 0.000 & 0.000 \\
\hline Robust Hausman test & 5.95 & 2.96 & 2.25 \\
\hline $\mathrm{p}$-value & 0.745 & 0.966 & 0.987 \\
\hline Part B & & Moody's & \\
\hline Dependent variable & Moody's (A) & Moody's (B) & Moody's (C) \\
\hline Variable of interest & User & User & User \\
\hline Chow test & 20.27 & 30.62 & 30.81 \\
\hline $\mathrm{p}$-value & 0.000 & 0.000 & 0.000 \\
\hline Breusch-Pagan test & 934.25 & $1,207.06$ & 922.76 \\
\hline $\mathrm{p}$-value & 0.000 & 0.000 & 0.000 \\
\hline Robust Hausman test & 5.05 & 5.78 & 37.99 \\
\hline $\mathrm{p}$-value & 0.830 & 0.762 & 0.000 \\
\hline
\end{tabular}

Source: Elaborated by the authors.

Based on the results in Table 6, it is verified that the three statistical models proposed for S\&P's and two proposed for Moody's were produced based on the regressions, using robust RE, as shown in tables 7 and 8. It warrants mentioning that the econometric model, based on Moody's categorization C, was produced with robust FE, as according to Table 6 .
After the panel data adherence tests, we revealed the results obtained based on the use of categorizations $\mathrm{A}, \mathrm{B}$, and $\mathrm{C}$ (as according to Table 3 ). These results are reported in tables 7 and 8, showing, respectively, the results for S\&P's and Moody's in each one of the tables.

Table 7

Regressions result - Standard \& Poor's (S\&P's) ratings (variable of interest: User)

\begin{tabular}{|c|c|c|c|}
\hline Dependent variable & S\&P's (A) & S\&P's (B) & S\&P's (C) \\
\hline Variables & Robust RE & Robust RE & Robust RE \\
\hline \multicolumn{4}{|l|}{ User } \\
\hline Coefficient & -0.1843 & -0.2517 & -1.0389 \\
\hline Z-score & -1.0700 & -1.1600 & -1.6000 \\
\hline p-value & 0.2842 & 0.2449 & 0.1097 \\
\hline \multirow{3}{*}{ General liquidity (-) } & -0.1702 & -0.2794 & -1.2720 \\
\hline & -1.0500 & -1.4500 & -2.7600 \\
\hline & 0.2935 & 0.1471 & 0.0057 \\
\hline \multirow{3}{*}{ Liabilities/(L+NE) (+) } & 0.7193 & 0.8415 & 2.4065 \\
\hline & 2.4800 & 2.2300 & 2.4600 \\
\hline & 0.0132 & 0.0261 & 0.0139 \\
\hline \multirow{3}{*}{ EBIT/financial expenses (-) } & 0.0001 & 0.0001 & 0.0001 \\
\hline & 1.1300 & 0.9400 & 0.5300 \\
\hline & 0.2572 & 0.3498 & 0.5964 \\
\hline \multirow{3}{*}{$\mathrm{ROI}(+)$} & -0.0038 & -0.0051 & -0.0180 \\
\hline & -0.9600 & -1.0800 & -1.4600 \\
\hline & 0.3354 & 0.2812 & 0.1435 \\
\hline
\end{tabular}


Table 7

Cont.

\begin{tabular}{|c|c|c|c|}
\hline Dependent variable & S\&P's (A) & S\&P's (B) & S\&P's (C) \\
\hline \multirow{3}{*}{ NL (assets) (-) } & -0.1479 & -0.2272 & -0.7915 \\
\hline & -2.8400 & -3.0300 & -4.5500 \\
\hline & 0.0045 & 0.0024 & 0.0000 \\
\hline \multirow{3}{*}{ Leverage (+) } & -0.0002 & -0.0006 & -0.0009 \\
\hline & -0.6300 & -1.9500 & -1.1800 \\
\hline & 0.5275 & 0.0515 & 0.2371 \\
\hline \multirow{3}{*}{ Volatility (+) } & -0.0014 & -0.0010 & -0.0024 \\
\hline & -2.7400 & -1.7900 & -1.7000 \\
\hline & 0.0061 & 0.0731 & 0.0890 \\
\hline \multirow{3}{*}{ Beta $(+)$} & -0.0009 & -0.0001 & -0.0251 \\
\hline & -0.0700 & -0.0100 & -0.4300 \\
\hline & 0.9478 & 0.9950 & 0.6658 \\
\hline \multirow{3}{*}{ Constant } & 6.0195 & 8.5538 & 25.3082 \\
\hline & 6.9300 & 6.4300 & 8.2800 \\
\hline & 0.0000 & 0.0000 & 0.0000 \\
\hline $\mathrm{N}$ & 934 & 934 & 934 \\
\hline \multicolumn{4}{|l|}{$r^{2}$} \\
\hline $\mathrm{r}^{2} \mathrm{O}$ & 0.2008 & 0.2264 & 0.2534 \\
\hline $\mathrm{r}^{2}-\mathrm{b}$ & 0.2890 & 0.3234 & 0.3188 \\
\hline $\mathrm{r}^{2}{ }_{-} \mathrm{w}$ & 0.1230 & 0.1097 & 0.1958 \\
\hline \multicolumn{4}{|l|}{$\mathrm{F}$} \\
\hline chi $^{2}$ & 48.0237 & 30.1184 & 51.6512 \\
\hline
\end{tabular}

Note: Note that the ratings are on a scale that follows the studies of Cheng and Subramanyam (2008), Damasceno et al. (2008), Johnston et al. (2009), Bonsall et al. (2015), Batta et al. (2016), and Lobo et al. (2017). Thus, the better the company's score, the lower the numeric scale. In light of this, it is important to highlight that a negative relationship between the User variable and the ratings means that the companies using derivatives received the best scores. Similarly, a positive coefficient indicates that the companies that used derivatives were those that received the worst scores.

$R E=$ random effects; $E B I T=$ earnings before interest and taxes; $N L=$ natural logarithm; $L=$ total liabilities; $N E=$ net equity; ROI = return on investment.

Source: Elaborated by the authors.

The results reported in Table 7 reveal that, for S\&P's, the use of derivative financial instruments was not reflected (positively or negatively) in the ratings issued. This is revealed in the coefficients of the three regressions, in which the p-values of $0.2842,0.2449$, and 0.1097 were found for categorizations A, B, and C, respectively. These numbers reveal that there was no statistically significant influence of derivatives use on the scores issued by this credit rating agency.

This result indicates that the hedge stated by the companies that used derivatives was not perceived and incorporated by this rating agency as a positive (or negative) aspect of financial policy. In addition, the main practical implication of this result is that the evaluation of companies by rating agencies may not consider multiple sources of data and information. Above all, it is important to highlight that the aspects inherent to the benefits of derivatives use and, consequently, the risks of this use, appear not to have been incorporated by S\&P's.

This result is consistent with the one highlighted by Ederington (1985); that is, ratings agencies may not consider more variables, such as derivatives use, than a statistical model can incorporate. Considering the results reported in Table 7, it is verified that around $30 \%$ of the ratings alterations can be explained by the joint variation in the variables inserted into the statistical model proposed here. This information can be verified based on the $\mathrm{r}^{2}$ analysis (more specifically $\mathrm{r}^{2}$ b) of around $30 \%$ for the three categorizations proposed.

In addition, although Koonce et al. (2015) also highlighted that the derivatives used for risk management were viewed positively by investors, the results reported here, linked to the perceptions of the ratings agencies, vary from this perspective. Based on this, the results are aligned 
with what was pointed out by Claußen et al. (2014); that is, ratings are insufficient metrics for measuring and capturing the risks of structured financial products such as derivatives.

With relation to the control variables, for S\&P's, the variations in the indicators that can explain the ratings alterations were: general liquidity; the percentage of third- party capital in the capital structure; volatility; and the size of the companies (defined as the neparian logarithm of the value of the company's total assets). These results are consistent with what was highlighted by Kraft (2015); that is, agencies use accounting information in their evaluations.

The results of the models for Moody's are described in Table 8.

Table 8

Regressions results - Moody's ratings (variable of interest: User)

\begin{tabular}{|c|c|c|c|}
\hline Dependent variable & Moody's (A) & Moody's (B) & Moody's (C) \\
\hline Variables & Robust RE & Robust RE & Robust FE \\
\hline \multicolumn{4}{|l|}{ User } \\
\hline Coefficient & 0.0916 & 0.1267 & 2.2134 \\
\hline Z-score & 0.3800 & 0.4300 & 2.2400 \\
\hline $\mathrm{p}$-value & 0.7014 & 0.6702 & 0.0361 \\
\hline $\mathrm{N}$ & 327 & 327 & 327 \\
\hline$r^{2}$ & & & 0.1513 \\
\hline $\mathrm{r}^{2} \mathrm{O}$ & 0.3886 & 0.3841 & 0.4364 \\
\hline$r^{2}-b$ & 0.6880 & 0.6859 & 0.3821 \\
\hline $\mathrm{r}^{2}{ }_{-} \mathrm{w}$ & 0.0598 & 0.0886 & 0.1513 \\
\hline \multicolumn{4}{|l|}{$\mathrm{F}$} \\
\hline $\mathrm{chi}^{2}$ & 149.1207 & 133.0141 & \\
\hline
\end{tabular}

Notes: Note that the ratings are on a scale that follows the studies of Cheng and Subramanyam (2008), Damasceno et al. (2008), Johnston et al. (2009), Bonsall et al. (2015), Batta et al. (2016), and Lobo et al. (2017). Thus, the better the company's score, the lower the numeric scale. In light of this, it is important to highlight that a negative relationship between the User variable and the ratings means that the companies using derivatives received the best scores. Similarly, a positive coefficient indicates that the companies that used derivatives were those that received the worst scores. The control variables were omitted from the table. $R E=$ random effects; $F E=$ fixed effects.

Source: Elaborated by the authors.

With relation to derivatives use, in these initial models we sought to verify whether the segregation between derivative users and non-users is identified and whether this information is incorporated by the agencies. Moody's negatively incorporated derivatives use, since the companies that used derivative financial instruments received worse ratings (coefficient of 2.2134 and p-value of 0.0361 ).

The interpretation of the results related to the use of derivatives and their incorporation by the ratings agencies appears to be aligned with what Campbell et al. (2015) indicated; that is, that analysts may not be correctly incorporating the information related to derivatives disclosed by companies, especially due to the nonconvergence of interpretation on the part of Standard \& Poor's and Moody's. If it is considered that the real purpose of derivatives use is not yet known (whether it is for hedging or for speculation), this divergence between the rating agencies appears to be coherent with the question raised in the study by Hentschel and Kothari (2001); that is, whether derivatives are used with the aim of increasing or reducing risks.

On this point, it is important to highlight that even for derivative users and controllers difficulty lies in interpretation and treatment, given the complexity and dynamics of these financial instruments. Along these lines, after applying a questionnaire, Bezzina and Grima (2012) reported that derivatives users and controllers answered that they are able to deal with derivatives, even in complex situations. At the same time, and surprisingly, the same respondents indicated that they have no specialist knowledge for dealing with derivatives in complex positions. This duality may help to explain the results reported here; that is, due to the complex dynamics of these instruments, the attribution of worse (Moody's) and indifferent (S\&P's) ratings to the companies that used derivative financial instruments is understandable. 
The results of incorporating information related to notional value and the impact on the ratings are reported in Table 9.

Table 9

Regressions result - Standard \& Poor's (S\&P's) and Moody's (variable of interest: Notional)

\begin{tabular}{|c|c|c|c|c|c|c|}
\hline $\begin{array}{l}\text { Dependent } \\
\text { variable }\end{array}$ & S\&P's (A) & S\&P's (B) & S\&P's (C) & Moody's (A) & Moody's (B) & Moody's (C) \\
\hline \multirow[t]{2}{*}{ Variables } & Robust RE & Robust RE & Robust RE & Robust RE & Robust RE & Robust FE \\
\hline & -0.1476 & -0.1348 & -1.1166 & -0.1689 & -0.1636 & -0.3968 \\
\hline \multirow[t]{2}{*}{ Notional } & -0.5300 & -0.4300 & -1.4400 & -2.3100 & -2.1500 & -2.1700 \\
\hline & 0.5931 & 0.6661 & 0.1498 & 0.0212 & 0.0316 & 0.0307 \\
\hline $\mathrm{N}$ & 707 & 707 & 707 & 253 & 253 & 253 \\
\hline$r^{2}$ & & & & & & 0.3278 \\
\hline $\mathrm{r}^{2} \mathrm{O}$ & 0.1165 & 0.1846 & 0.2256 & 0.0872 & 0.1123 & 0.2524 \\
\hline$r^{2}-b$ & 0.1827 & 0.3288 & 0.3732 & 0.5038 & 0.6823 & 0.0426 \\
\hline$r^{2}-w$ & 0.0959 & 0.0812 & 0.1418 & 0.1630 & 0.1735 & 0.3278 \\
\hline $\mathrm{F}$ & & & & & & 12.4092 \\
\hline chi $^{2}$ & 44.6490 & 64.9236 & 197.2501 & 55.0264 & 68.9656 & \\
\hline
\end{tabular}

Notes: Note that the ratings are on a scale that follows the studies of Cheng and Subramanyam (2008), Damasceno et al. (2008), Johnston et al. (2009), Bonsall et al. (2015), Batta et al. (2016), and Lobo et al. (2017). Thus, the better the company's score, the lower the numeric scale. In light of this, it is important to highlight that a negative relationship between the Notional variable and the ratings means that the companies that presented the highest notional values received the best ratings. Similarly, a positive coefficient indicates that the companies with the highest notional values were those that received the worse ratings. The control variables were omitted from the table.

$R E=$ random effects; $F E$ = fixed effects.

Source: Elaborated by the authors.

According to the results presented in Table 9, it can be verified that Moody's positively incorporates the size of the hedge; that is, those companies that presented the greatest positions in derivatives (higher notional values) were the ones that received the best ratings. These results were obtained for the three proposed categorizations and were statistically significant at $5 \%$. This result is revealed by the negative coefficients (and the respective p-values) in the three models, A, B, and C. The values found were -0.1689 (0.0212), $-0.1636(0.0316)$, and -0.3968 (0.0307), respectively.

It is also worth mentioning that the results reported in Table 9 are in opposition to the interpretation of the results related to derivatives use. With this, it can be inferred that, despite the hedge value being taken into consideration, there was no separation and reflection in the ratings from the use or not of derivatives. These findings indicate and reinforce the complexity of derivative financial instruments, as previously pointed out in the studies developed by Campbell et al. (2015) and Chang et al. (2016).

It needs to be highlighted that Chang et al. (2016) argued that derivatives are complex contracts and create a significant challenge for reporting this information. Based on their results, the authors conceptualized that analysts' profit forecasts for new companies using derivatives are less precise and more dispersed after these financial instruments start to be used. Campbell et al. (2015) found that analysts do not correctly incorporate into their profit forecasts the hedging gains and losses from unrealized cash flow.

With relation to the incorporation of notional value by S\&P's, the results obtained in this research do not enable it to be affirmed that there was a statistically significant influence of the notional value on the rating attributed in the three categorizations. This finding aligns with the non-perception of the use of derivatives identified previously. The results are consistent with what was previously highlighted by Chang et al. (2016). The researchers indicated that, despite analysts' expertise, they routinely misjudge the implications on profits derived from the effect of the activities inherent to the use of derivatives by companies. Although derivative financial instruments can reflect relevant negative impacts on companies' profits, the use of these instruments was not adequately incorporated by S\&P's and Moody's.

The difficulty in incorporating the information related to derivatives use was highlighted and reported by Chung, Kim, Kim, and Yoo (2012) and by Antônio et al. (2019). According to Chung et al. (2012), despite the 
previous studies suggesting that the level of disclosure is positively related with stock market efficiency, investors are more likely to erroneously evaluate losses related to derivatives. Antônio et al. (2019) reported that, although analysts presented less bias when forecasting earnings per share and did not present any bias in revenues forecasts, EBITDA forecasts were more biased. It is worth mentioning that these results may be associated with the derivatives classified by fair value by means of earnings and present direct impacts on operating profit, making the incorporation of this information difficult.

It also needs to be remembered that this notional value variable was weighted by the total value of the companies' assets, in alignment with Hentschel and Kothari (2001). In this study, Hentschel and Kothari (2001) found that there was no association between the volatility of companies' share prices and the values of the derivatives positions (notional values), which indicates that the market did not perceive those companies with high notional values as being more risky. Meanwhile, in the results reported here, one of the ratings agencies, Moody's, appears to perceive the companies with the highest notional values as being concerned about protecting themselves from undesirable variations in interest rates, exchange rates, and commodity prices, for example.

With the aim of providing the results with more robustness, Table 10 shows the results of the BreuschPagan/Cook-Weisberg tests for heteroscedasticity, the average of the variance inflation factor (VIF) test, and the Wooldridge test for autocorrelation in panel data.

Table 10

$T$ Tests for verifying heteroscedasticity and autocorrelation of the models

\begin{tabular}{|c|c|c|c|c|c|c|}
\hline \multirow{2}{*}{$\begin{array}{c}\text { Part A - Variable of interest } \\
\text { Model }\end{array}$} & \multicolumn{6}{|c|}{ User } \\
\hline & S\&P's (A) & S\&P's (B) & S\&P's (C) & Moody's (A) & Moody's (B) & Moody's (C) \\
\hline $\begin{array}{l}\text { Breusch-Pagan/Cook-Weisberg test for } \\
\text { heteroscedasticity }\end{array}$ & 22.060 & 232.620 & 479.460 & 29.740 & 79.240 & 97.510 \\
\hline p-value & 0.000 & 0.000 & 0.000 & 0.000 & 0.000 & 0.000 \\
\hline Average VIF & 1.100 & 1.100 & 1.100 & 1.290 & 1.290 & 1.290 \\
\hline Wooldridge test for autocorrelation in panel data & 299.428 & 159.067 & 47.857 & 1966.457 & 1952.623 & 812.911 \\
\hline p-value & 0.000 & 0.000 & 0.000 & 0.000 & 0.000 & 0.000 \\
\hline Part B - Variable of interest & \multicolumn{6}{|c|}{ Notional Value } \\
\hline $\begin{array}{l}\text { Breusch-Pagan/Cook-Weisberg test for } \\
\text { heteroscedasticity }\end{array}$ & 7.690 & 54.310 & 54.430 & 1.390 & 2.250 & 1.470 \\
\hline p-value & 0.006 & 0.000 & 0.000 & 0.239 & 0.134 & 0.225 \\
\hline Average VIF & 1.120 & 1.120 & 1.120 & 1.270 & 1.270 & 1.270 \\
\hline Wooldridge test for autocorrelation in panel data & 153.237 & 102.104 & 51.432 & 1963.274 & 2225.929 & 331.647 \\
\hline p-value & 0.000 & 0.000 & 0.000 & 0.000 & 0.000 & 0.000 \\
\hline
\end{tabular}

$S \& P=$ Standard \& Poor's; VIF = variance inflation factor.

Source: Elaborated by the authors.

The results of the tests presented in Table 10 indicate that the residuals of the estimations are not homoscedastic, therefore the models were estimated with a robust variancecovariance matrix, and there are no multicollinearity problems or autocorrelation problems among the data.
Based on the results presented and analyzed here, the next section presents the concluding remarks with the main implications of this study, as well as the limitations and suggestions for future research related to the topic addressed here.

\section{CONCLUDING REMARKS}

The aim of this study was to investigate whether companies that use derivative financial instruments, especially those that use them for hedging purposes, received better credit ratings in comparison with those that did not use these instruments. This research relationship with elaborated given that some credit ratings seek to capture subjective aspects of the companies evaluated, such as those related to business profile and to financial policies. In addition, another relevant point, which concerns the research relationship 
analyzed, concerns the fact that companies may carry out part of their risk management based on the use of derivatives.

In light of the points raised previously and what the literature highlights, it can be noted that the information related to the use of derivatives is complex, thus making it difficult to completely incorporate this information into the analyses carried out by ratings agencies. The complexity of this information was addressed and listed according to the arguments presented in the studies by Campbell et al. (2015), Chang et al. (2016), and Antônio et al. (2019).

In light of this, it is important to fill the gap that has not yet been explored by the academic literature from the area, reporting the impact on companies' ratings based on the use or not of these instruments and on the value hedged by the derivatives. Reinforcing this aspect, Akins (2017) highlighted that there are few studies that have addressed "if" and "how" the quality of financial reports influences credit rating agencies and their ratings. Based on this context, we sought to answer the following question: do companies that use derivative financial instruments for hedging receive the best credit ratings?

Based on the proposed models and the research relationship identified, the results obtained suggest that derivatives use is not completely incorporated by the credit rating agencies investigated. In addition, the results do not enable it to be inferred that S\&P's attributed better credit ratings to companies that used hedge derivatives. In turn, Moody's appears to recognize derivatives use as a negative aspect, due to its attribution of worse scores to companies that made use of these financial instruments when compared to companies that did not.

With relation to notional value, there are indications that S\&P's does not recognize hedging based on the notional value of companies. However, S\&P's appears not to perceive the speculative aspects of the use of these instruments. In turn, Moody's attributed the best ratings to companies that presented the highest notional values. At first glance, as the totality of companies studied stated that it makes use of derivatives for hedging purposes, the value of the positions is perceived as a positive aspect by Moody's. Thus, the core hypothesis of this study is rejected; that is, that companies that use derivative financial instruments for hedging purposes received the best credit ratings.

These results are aligned with the points previously made in the studies by Campbell et al. (2015), Chang et al. (2016), and Antônio et al. (2019); that is, there is no convergence yet in the evaluations carried out by agencies and by their analysts regarding derivatives use and the information disclosed that is inherent to this use. Along these lines, Valle (2002) highlighted that, when companies from a particular country have the same credit rating and there is strong evidence of different evaluations for these companies, it is possible to argue that the ratings attributed by the agencies are, sometimes, of limited rigor and questionable value.

As a main implication of the results obtained, it can be inferred that there is no homogenous interpretation of the information disclosed regarding derivatives use. These instruments have not yet been perceived as tools used to increase or reduce corporate risks, as reported, previously, by Hentschel and Kothari (2001), regarding the public discussion of derivatives use.

Although Koonce et al. (2015) consider that the derivatives used for risk management were viewed positively by investors, the results reported here, linked to the perceptions of the ratings agencies, differ in this respect. The results are consistent with what was highlighted by Claußen et al. (2014); that is, the ratings analyzed here were insufficient metrics for measuring the risks of structured financial products, such as derivative financial instruments.

According to Chung et al. (2012), the previous studies indicated that the level of disclosure is positively related to stock market efficiency. However, it is more likely that investors erroneously evaluate the losses related to derivatives. The results obtained based on this research are limited and reflect the institutional environment of the Brazilian market in the period investigated, which covers 2010 to 2016. In addition, the results are restricted to the variables of control and interest used in the models proposed here. Future research could analyze other variables capable of explaining the alterations and ratings issued by credit rating agencies. 


\section{REFERENCES}

Akins, B. (2017). Financial reporting quality and uncertainty about credit risk among ratings agencies. The Accounting Review, 93(4), 1-22.

Antônio, R, M., Lima, F. G., Santos, R. B., \& Rathke, A. A. T. (2019). Use of derivatives and analysts' forecasts: new evidence from non-financial Brazilian companies. Australian Accounting Review, 29(1), 220-234.

Batta, G. E., Qiu, J., \& Yu, F. (2016). Credit derivatives and analyst behavior. The Accounting Review, 91(5), 1315-1343.

Bezzina, F. H., \& Grima, S. (2012). Exploring factors affecting the proper use of derivatives: An empirical study with active users and controllers of derivatives. Managerial Finance, 38(4), 414-435.

Bodie, Z., Kane, A., Marcus, A. J. (2014). Investimentos (10th ed.). Porto Alegre, RS: AMGH.

Bodnar, G. M., \& Gebhardt, G. (1999). Derivatives usage in risk management by US and German non-financial firms: A comparative survey. Journal of International Financial Management \& Accounting, 10(3), 153-187.

Bonsall, S., Koharki, K., \& Neamtiu, M. (2015). The effectiveness of credit rating agency monitoring: Evidence from asset securitizations. The Accounting Review, 90(5), 1779-1810.

Campbell, J. L. (2015). The fair value of cash flow hedges, future profitability, and stock returns. Contemporary Accounting Research, 32(1), 243-279.

Campbell, J. L., Downes, J. F., \& Schwartz, W. C. (2015). Do sophisticated investors use the information provided by the fair value of cash flow hedges? Review of Accounting Studies, 20(2), 934-975.

Chang, H. S., Donohoe, M., \& Sougiannis, T. (2016). Do analysts understand the economic and reporting complexities of derivatives? Journal of Accounting and Economics, 61(2-3), 584-604.

Cheng, M., \& Subramanyam, K. R. (2008). Analyst following and credit ratings. Contemporary Accounting Research, 25(4), 1007-1044.

Chung, J., Kim, H., Kim, W., \& Yoo, Y. K. (2012). Effects of disclosure quality on market mispricing: Evidence from derivative-related loss announcements. Journal of Business Finance \& Accounting, 39(7-8), 936-959.

Claußen, A., Löhr, S., \& Rösch, D. (2014). An analytical approach for systematic risk sensitivity of structured finance products. Review of Derivatives Research, 17(1), 1-37.

Comitê de Pronunciamentos Contábeis. (2016). Instrumentos Financeiros. Retrieved from http://www.cpc.org. br/CPC/Documentos-Emitidos/Pronunciamentos/ Pronunciamento? Id=106.

DaDalt, P., Gay, G. D., \& Nam, J. (2002). Asymmetric information and corporate derivatives use. Journal of Futures Markets: Futures, Options, and Other Derivative Products, 22(3), 241-267.

Damasceno, D. L., Artes, R., \& Minardi, A. M. A. F. (2008). Determinação de rating de crédito de empresas brasileiras com a utilização de índices contábeis. Revista de Administração-RAUSP, 43(4), 344-355.
DeHaan, E. (2017). The financial crisis and corporate credit ratings. The Accounting Review, 92(4), 161-189.

Donohoe, M. P. (2015). The economic effects of financial derivatives on corporate tax avoidance. Journal of Accounting and Economics, 59(1), 1-24.

Ederington, L. H. (1985). Classification models and bond ratings. Financial review, 20(4), 237-262.

Financial Accounting Standards Board. (1999). Accounting for derivative instruments and hedging activities. Retrieved from http://fasb.org/pdf/aop_FAS133.pdf.

Fischer, T. (2015). Market structure and rating strategies in credit rating markets - A dynamic model with matching of heterogeneous bond issuers and rating agencies. Journal of Banking \& Finance, 58(1), 39-56.

Freitas, A. D. P. N., \& Minardi, A. M. A. F. (2013). The impact of credit rating changes in Latin American stock markets. BARBrazilian Administration Review, 10(4), 439-461.

Gelbcke, E. R., Santos, A. dos, Iudícibus, S. de, \& Martins, E. (2018). Manual de contabilidade societária: aplicável a todas as sociedades: de acordo com as normas internacionais e do CPC. São Paulo, SP: Atlas.

Guay, W. R. (1999). The impact of derivatives on firm risk: An empirical examination of new derivative users1. Journal of Accounting and Economics, 26(1-3), 319-351.

Gujarati, D. N., \& Porter, D. C. (2011). Econometria básica (5th ed.). São Paulo, SP: AMGH.

Hentschel, L., \& Kothari, S. P. (2001). Are corporations reducing or taking risks with derivatives? Journal of Financial and Quantitative Analysis, 36(1), 93-118.

Hsueh, L. P., \& Liu, Y. A. (1992). Market anticipation and the effect of bond rating changes on common stock prices. Journal of Business Research, 24(3), 225-239.

Hull, J. C. (2016). Opções, futuros e outros derivativos. Rio de Janeiro, RJ: Bookman.

Hull, J., Predescu, M., \& White, A. (2004). The relationship between credit default swap spreads, bond yields, and credit rating announcements. Journal of Banking \& Finance, 28(11), 2789-2811.

International Financial Reporting Standards. (2018). Financial Instruments. Retrieved from https://www.ifrs.org/issuedstandards/list-of-standards/ifrs-9-financial-instruments/.

Johnston, R., Markov, S., \& Ramnath, S. (2009). Sell-side debt analysts. Journal of Accounting and Economics, 47(1-2), 91-107.

Kawaller, I. G. (2004). What analysts need to know about accounting for derivatives? Financial Analysts Journal, 60(2), 24-30.

Kisgen, D. J. (2006). Credit ratings and capital structure. The Journal of Finance, 61(3), 1035-1072.

Koonce, L., Lipe, M. G., \& McAnally, M. L. (2008). Investor reactions to derivative use and outcomes. Review of Accounting Studies, 13(4), 571-597.

Koonce, L., Miller, J., \& Winchel, J. (2015). The effects of norms on investor reactions to derivative use. Contemporary Accounting Research, 32(4), 1529-1554. 
Kraft, P. (2015). Rating agency adjustments to GAAP financial statements and their effect on ratings and credit spreads. The Accounting Review, 90(2), 641-674.

Lee, Y. J. (2008). The effects of employee stock options on credit ratings. The Accounting Review, 83(5), 1273-1314.

Li, J., Shin, Y. S., \& Moore, W. T. (2006). Reactions of Japanese markets to changes in credit ratings by global and local agencies. Journal of Banking \& Finance, 30(3), 1007-1021.

Lobo, G. J., Paugam, L., Stolowy, H., \& Astolfi, P. (2017). The effect of business and financial market cycles on credit ratings: Evidence from the last two decades. Abacus, 53(1), 59-93.

Murcia, F. C. D. S., Dal-Ri Murcia, F., Rover, S., \& Borba, J. A. (2014). The determinants of credit rating: Brazilian evidence. BAR-Brazilian Administration Review, 11(2), 188-209.
Plumlee, M. A. (2003). The effect of information complexity on analysts' use of that information. The Accounting Review, 78(1), 275-296.

Tonin, J. M., \& Colauto, R. D. (2015). Relação entre income smoothing e ratings em companhias brasileiras de capital aberto. Contabilidade Vista \& Revista, 26(1), 104-122.

Valle, M. R. (2002). Mercados de bonds: risco, rating e custo de captação. Revista de Administração da Universidade de São Paulo, 37(2), 46-56.

Wooldridge, J. M. (2006). Introdução à econometria: uma abordagem moderna. São Paulo, SP: Pioneira Thomson Learning.

Wooldridge, J. M. (2010). Econometric analysis of cross section and panel data. Cambridge, MA: The MIT Press. 